\title{
Terrorism and the Military Institution: History and Definitions
}

\author{
Kwame Badu Antwi-Boasiako ${ }^{1 *}$, John HamiHasbun ${ }^{2}$ \\ ${ }^{l}$ Full professor and chair of the Department of Government, Stephen F. Austin State University, Nacogdoches, \\ Texas, 75962 \\ ${ }^{2}$ MPA, Stephen F. Austin State University, Nacogdoches, Texas, 75962
}

*Corresponding Author: Kwame Badu Antwi-Boasiako, IFull professor and chair of the Department of Government, Stephen F. Austin State University, Nacogdoches, Texas, 75962

\begin{abstract}
Recent narratives on terrorism have focused on the definitions. Terrorism is not a new phenomenon but the problem resides in its definition and who is defining it. Conceptualizing terrorism depends on which framework one utilizes. The use of different lenses to define a crime has contributed to lack of global acceptance of what constitutes terrorism hence the difficulty of gathering data for analysis. It is also a conundrum when a powerful nation legitimizes its terrorist activities against a weaker one through the use of military power. This, unfortunately, has led to the subjectiveness of every attempt in the literature to objectively provide a globally acceptable definition. This article looks at a brief history of the military as an institution and how it has been, and continues to be used as an instrument of terror by political leaders. The paper questions the activities of the military and concludes we are all guilty of terrorism.
\end{abstract}

Keywords: Terrorism, Colonization, Slave Masters, Military, Freedom Fighters, Natives.

\section{INTRODUCTION}

While no nation is immune from acts of terrorism, all nations through their military institutions perfect how they can terrorise each other. For example, citizens of the United States of America (USA), arguably, used to believe that they were protected from terror by oceans until the attacks of September 11, 2001 (9/11) (Gage 2011). Given the geo-location and the natural design of the earth, many nations have never been afforded the luxury of such delusions. Since the genesis of recorded history, nations have been subjected to the destruction and violence associated with acts of terrorism using their militia, military, or asafo companies to professionally engage in well-orchestrated atrocities (terrorism) in the name of defense or protecting their colonies and political ideologies.Terrorism is seen as a socio politically constructed term with multiple definitions, which may originate from a variety of sources and directions given how individuals, societies, cultures, or nations defining it (Fine 2010). There are several types of terrorism in the academic literature, which include but are not limited to: civil disorder, political terrorism, non-political terrorism, quasiterrorism, limited political terrorism, and state sponsored terrorism, slavery and colonization. This paper concerns itself primarily with political and state terrorism, as it examines the definitions of terrorism, and its relationship to the military as an institution, which trains to kill and destroy in the name of defense and peace.

The paper begins by tracing the history of terrorism as an act and a concept. It tries to explicate the various definitions of terrorism and the conundrum of reaching international consensus on defining the term. Additionally, the paper soupcons the origins of the military as an institution and examines its role in terrorism. This article culminates in the examination of the relationship between terrorism and the military and why military force would never end terrorism since the institution itself is guilty of what it claims to be fighting against. The term military is used broadly here to include the navy, air force, and infantry, in fact, all branches of the military and it is discussed as one global institution; therefore, there is no difference between the USA, Iran, Iraq, the British, South Africa, Ghana, North

\footnotetext{
${ }^{1}$ These are militia groups formed by local tribes to protect the various clans in Ghana. They police or act as the military to defend the interest of a given society and fight wars when necessary. They protect their chiefs and indigenous populations and are seen as warriors.
} 
Korea, or the Chinese military. While the differences among the various institutions as a "matter of interpretation" might differ from country to country, the didactic history of the military's doctrine and "general rational" are theoretically and arguably the same (Hoiback 2013, 25).

\section{BRIEF HISTORY OF TERRORISM: AN OVERVIEW}

The nature of terrorism has evolved since its fledging beginnings. That is, the origin of terrorism could be as old as when humans started employing violence against each other's behaviour. There is this idea in the literature where scholars argue that modern terrorism began with the French Revolution- a period of social and political upheaval from 1789 to 1799- and has been evolving since then. We argue strongly that terrorism may be traced to the genesis of creation and its shared causes or goals have never changed. Some of these common causes may include, but not limited to, land ownership, cultural differences, religion, Israeli-Palestinian conflict, the USA invasion of Iraq, the USSR invasion of Afghanistan, colonization, slavery, national and political sovereignty.

In $70 \mathrm{AD}$, Josephus Flavius referred to a sect of Jewish zealots named the Sicarii who used assassinations as a tactic in the Jewish rebellion against Rome (Fine 2010). Kaplan (2011) maintains this was "the first recorded case of terrorism" (104). The Sicarii were organized by Judas of Galilee who incited people to revolt against "tyranny of the Roman Empire financial enslavement" (Zeitlin1965, 302). However, the Sicarii did not limit their aggression to the Roman State but extended their attack on those civilians who willingly submitted to the authority of Rome (Smith 1971). The Sicarii felt their acts against the Judeans were justified because they did not agree with their political aspirations. In fact, it is believed, it was the Jews who first attempted to name the use of terror in a political context though it was the Assyrians who first developed the terminology for the use of political and military "means to inspire terror" (Fine 2010,271).

While terrorism might be going on for political reasons and accomplishments in the eyes of political leaders, this is perhaps the first instance where terror was seen as an evil act with negative connotation. However, during the French Revolution, the term "terrorism" had a positive connotation (Hoffman 2006). The concept of terror employed as a political idea was first utilized by the French Legislature in order to "suppress the aristocratic threat to the revolutionary government" (Bahan 2009,336). The leader of the so-called "reign of terror", Robespierre, "stands apart as the first politician to organize and mobilize the resources of a modern nation to systematically eradicate his opponents" by dehumanizing them (Fine 2010, 278). Robespierre's regime de la terreur(reign of terror) shares at least two familiar characteristics in common with what may be described as the modern-day acts of terrorism. First the "reign of terror" (the use of the military) was well organized; second, its goal and justification were the creation of a "new and better" society in place of a fundamentally corrupt system (Hoffman 2006, 16). Differing from their successors, the leaders of the reign of terror typically shirked intentional military attacks against innocent civilians in order to maintain "political legitimacy" (Bahan 2009,336) similar to nations such as the USA, Great Britain, France, Germany, Spain, Portugal, and others that engaged in legalized occupation of native lands, slavery, and colonization. Their activities had state endorsement and the structural organization of their atrocities was chronologically mapped out. Robespierre believed that "...terror without which virtue is powerless" (Fine 2010, 278).

\subsection{The Natives, Wars, and Terrorism}

Until the eve of the First World War (WWI), terrorism retained its positive revolutionary connotation. However, by the 1930s, terrorism was commonly used to describe the practice of mass repression in totalitarian states, used by dictatorial leaders against their own citizens, a practice that became so common in most African countries after gaining political independence from the evils of slavery and colonization (Hoffman2006). Joseph Stalin (1879-1953), for instance, unleashed the "Great Terror" upon Russia and meant to "seize total power by terrorist action" (Hoffman 2006, 25). However, this connation did not last much past WWII, after which the meaning of terror changed again. One of the biggest gaps in tracing the origin of terrorism and what constitutes terrorism is the focus on authoritarian and dictatorial regimes. But as it is evident in the literature, democratic countries also use their military to terrorise others. For example, Great Britain (treatment of the natives in the colonized; Africa and Australia), the USA (treatment of Native American Indians) (Matthews 2002) and the Portuguese in Brazil or Spain in South American countries (Fausto1999). In the post-WWII era, those considered terrorists began targeting innocent civilians as means to "inspire media coverage 
and effect political change in targeted governments" (Bahan 2009, 337). It became the norm for violence to be actively used in nations not directly involved in conflicts in which innocent civilians were attacked for political and ideological reasons.

The concept of terrorism in a revolutionary context expanded in the 1960s and 1970s to include ethnic separatist groups, the disenfranchised, or exiled nationalist minorities. However, these groups often rejected the label "terrorists," preferring instead to be referred to as "liberators" or "freedom fighters" (Hoffman2006).In the 1940s-1960s, individuals and groups in colonized African countries that began to fight for their political independence were not only seen as dangerous and terrorists but were also the targets of the colonizers (Anderson 2005; Elkins 2005). By the 1980s, terrorism evolved to new dimensions where, arguably, more frustrated, disfranchised, and marginalized individuals and groups rebelled against powerful authorities. Unfortunately, in what the literature describes as modern terrorism, it is not uncommon for individuals to act alone to cement their agenda through social media, or as a result of extensive global media coverage. While one may not be able to pin point the genesis of terrorism, its unfortunate violence and atrocities have escalated as a result of technological advancement in general, including the use of the military institution to achieve political and individual ambition.

The modern military, for example, does not have to directly or physically confront its so-called enemies any more. Instead, it uses technology, such as missiles, bombs, and chemical weapons that can be dropped at a given geographical location killing and destroying everything within that area. Civilian casualties have become common in military atrocities among nations under the disguise of fighting terrorism. So, what is terrorism? An attempt is made here to define or conceptualize these acts of barbarism. Unfortunately, it has become a political tool of convenience where the wellorganized and powerful nations utilized their military to suppress and threaten weaker societies or nations.

\subsection{Defining Terrorism: Who's Definition Works?}

According to Cronin $(2005,341)$, "terrorism is notoriously difficult to define, in part because the term has evolved and... it is associated with an activity that is designed to be subjective."Many studies argue that an "objective and internationally accepted definition of terrorism can never be agreed upon... since one man's terrorist is another man's freedom fighter" (Ganor 2002). ${ }^{2}$ The struggle in the search for a suitable globally acceptable definition seems impossible "because different bodies, organizations, and government agencies have different definitions to suit their own particular (political) role, purpose, or bias" (Bruce2013, 26). Hunter $(1991,352)$ sees terrorism as "a political phenomenon aimed at achieving politically determined goals." For example, the slave and colonial masters did not see themselves as engaging in acts of terrorism. So would the nations that engaged in slavery and colonization for centuries consider themselves as supporters of terrorism? Affirming Bruce's submission, Carr (2007) argues there are no two agencies within the US government, for example, that have "identical" definitions. In most cases, agencies cannot reconcile on the definition of terrorism.

While no one seems to have any trouble recognizing terrorism, agreeing upon a satisfactory definition proves more elusive. It is a complicated phenomenon, which requires a sophisticated strategy in achieving its goals. The League of Nations first attempted to define international terrorism in 1937 as a response to the assassination of the Yugoslavian Head of State, King Alexander I and "the President of the Council of the French Republic, Louis Bathou" (Bahan 2009,344). Unfortunately, while the convention was adopted, it never came to fruition (Young 2006). Currently, there is a plethora of definitions of terrorism available in the literature, which tend to contradict each other.

\section{COMPARING DEFINITIONS}

The Oxford English Dictionary provides a number of possible definitions for terrorism. The most applicable for our purpose being: "a policy intended to strike with terror those against whom it is adopted."A terrorist is defined as "anyone who attempts to further his views by a system of coercive intimidation" (Hoffman 2006, 14).

\footnotetext{
${ }^{2}$ See also Laqueur Walter (1987). The age of terrorism. Little Brown and Company, Boston.
} 
Gupta (2011) defines terrorism as a political act by non-state actors, where participants, in contrast to common criminals, see their acts as a way of achieving public good, such as national independence, social justice, or "the establishment of a theocratic state, thus making them altruist in their own minds" (99). Those who find this definition limiting may find more satisfaction in Ganor's (2002) definition of terrorism as "the deliberate use, or threat, of violence against civilians in order to attain political, ideological, and religious aims" (288).

Those seeking a definition from sanctioned governmental agencies rather than academics might prefer the US Department of State's definition of terrorism contained in Title 22 of the United States Code Section $2656 \mathrm{f}$ (d). It defines terrorism as "premeditated, politically motivated violence perpetrated against other non-combatant targets by subnational groups or clandestine agents." The US Federal Bureau of Investigation (FBI), on the other hand, defines terrorism as "the unlawful use of violence against persons or property to intimidate or coerce government, the civilian population, or any segment thereof in furtherance of political or social objectives" (as cited by Hoffman 2006, 38). The US Department of Defence (DoD) takes a slightly different stance defining it as "the unlawful use of -or threatened use of- force or violence against individuals or property to coerce or intimidate governments or societies, often to achieve political, religious, or ideological objectives."

The United Nations (UN) has long struggled to settle on a definition of terrorism for global acceptance since its working definitions tend to accuse powerful nations of the very crime they claim to be fighting against. For years the UN avoided using the term "terrorism," even when specifically crafting policy to combat it, in order to avoid any political and ideological disputes surrounding the term (Saul 2005). In fact, the first time the UN actually used the term "terrorism" was in 1985 in the Security Council Resolution 579, which was crafted in response to "the excessive amount of global terror attacks" (44). Additionally, the first time a direct link was made between terrorism and violations of human rights dates back to the 1993 Vienna World Conference on Human Rights (Symonides 2001). The UN avoided making any declarative statement regarding a definition of terrorism until October 2004, when it adopted the Security Council Resolution 1566, which generally, but not expressively, defines terrorism as:

...criminal acts, including against civilians, committed with the intent to cause death or serious bodily injury, or taking of hostages with the purpose to provoke a state of terror in the general public or in a group of person or particular person, intimidate a population or compel a government or an international organization to or to abstain from doing any act which constitute offences within the scope and as defined in the international conventions and protocols relating to terrorism (Saul2005,164).

At the International Convention for the suppression financing terrorism, the UN once again made an indirect attempt to define terrorism as:

Any other act intended to cause death or serious bodily injury to a civilian, or to any other person not taking an active part in the hostilities in situation or armed conflict, when the purpose of such act, by its nature or contest is to intimidate a population or compel a government or an international organization to do or abstain from doing an act (Bahan 2009, 346).

However, it could be argued that the UN's best effort to define terrorism occurred at the Draft Comprehensive Convention on Terrorism, which sought to label terrorism a criminal offense if certain qualifications are met, describing a terrorist as:

Any person who commit an offence within the meaning of the present Convention if that person by any means unlawfully and unintentionally causes (a) Death or the serious bodily injury to any person; or (b) Serious damage to public or private property, including a place of public use, a State or government facility, a public transportation system, and infrastructure facility or to the environment; or (c) Damage to property, places, facilities, or systems referred to in paragraph 1 (b) of the present article resulting or likely to result in major economic loss; when the purpose to conduct, by its nature or contest, is to intimidate a population, or to complete a Government or international organization to do or abstain from doing an act (361). 
Of the definitions provided, it is those that specifically mention targeting civilian populations, which are most applicable to the argument concerning the differentiation between terrorists and freedom fighters. Here again, who decides which definition must be used? Will the nations that engaged in centuries of slavery and colonization, which were direct target on civilians admit that they supported, financed, and legalised terrorism? Every known war involves the killings of civilians but there is an attempt to differentiate these military criminal activities involved in killing or slaughtering of civilians as non-terrorist activity.

\title{
3.1. Terrorists or Freedom Fighters
}

The Palestine Liberation Organization's (PLO) Chairman, Yasser Arafat, including Nelson Mandela of South Africa, Muammar Al Gaddgafi of Libya, were more often than not labelled as terrorists but Arafat, for example, quibble rejected that label associated to him by Israel and the West claiming that "the difference between the revolutionary and the terrorist lies in the reason for which each fights" (Hoffman 2006, 26). In fact, many groups that commit acts of terror eschew the pejorative terrorism label and prefer to think of themselves instead as freedom fighters or liberators. Nelson Mandela wanted equality for all in South Africa by rejecting the evils of apartheid in that country, which was nocturnally supported by some Western countries, while Kwame Nkrumah of Ghana and others wanted total liberation for Africans who were buried in the oppressive rule of European colonial governments.

These views strike many as a massive rationalization. Those who supported the contention of Arafat and his ilk could argue that they were merely freedom fighters, hence the distinction. The same argument could be made for, or against, some African leaders such as Robert Mugabe, Nelson Mandela, Jomo Kenyatta, Kwame Nkrumah, and others who led groups, such as the MauMau, to fight the evils of the British colonization and occupation for independence and freedom. Ganor (2002) writes:

\begin{abstract}
What is important in these definitions is the differentiation between the goals and the means used to achieve these goals. The aims of terrorism and guerrilla warfare may well be identical; but they are distinguished from each other by the means used- or more precisely, by the targets of their operations. The guerrilla fighter's targets are military ones, while the terrorist deliberately targets civilians. By this definition, a terrorist can no longer claim to be a "freedom fighter" because they are fighting for national liberation or some other worthy goal (288).
\end{abstract}

The systematic and continuous targeting of civilians is and should be the principle qualifier in any definition of terrorism. The distinguishing between goals and the means by which the goals are achieved is a distinction that cannot be overstated. Terrorism is a tactic used to accomplish an objective, be it political, ideological, religion, or economical, but it is the indiscriminate targeting of civilians, which separated the modern-day terrorism from the Jacobin revolutionary.

So, would countries like France, Portugal, Britain, German, and the USA that enslaved or colonized other countries (mainly, non-combat civilians) be seen as nations that engaged in terrorism? Martin (2006) attempts to answer this question by identifying types of terrorism but provides some compelling definitions. His types of terrorism include: State, dissident, religious, and criminal. In his criminal definition of terrorism, Martin maintains "terrorism motivated by sheer profit, or some amalgam of profit and politics" (49) is criminal, hence slavery and colonization as the colonizers and slave masters including those states such as the USA, Britain, Portugal, France and other European countries profited from their criminal terrorist activities. In fact, as Fausto (1999) has argued, the slaves were used as tools of production to profit only the slave masters, and a slave could be sold as a commodity at any time for profit and economic reasons.

The problem of the definition conundrum is that the terrorism literature is skewed as a result of dependence on data provided by powerful nations (governments) and their agencies. So, if a government decides, which criminal activities constitute or fit terrorism then the said government would label it so. It is not uncommon for powerful nations dropping bombs on civilians in the name of preventing the spread of communism or fighting terrorism but those nations do not consider their actions as acts of terrorism. As Schmid and Jongman (2006) lamented, "The perception of political terrorism as a practical problem requiring urgent solution has led to poorly defined, ideologically 
biased, conceptually skewed research." That is, "policy-oriented research tends to impede sound theoretical work because of urgent social need (real or perceived) to achieve concrete results in the real world" (180).So, do we see the military as root of terrorism? Or does the military engage in terrorism? When a soldier kills, must it be considered a murder or what? Societies have moved away from moral righteousness to reward institutional murders in the name of defence and protection. Over two thousand years ago, a Chinese philosopher, Mo $\mathrm{Ti}^{3}{ }^{3}$ argued everyone ["knows that murder is unrighteous" yet "when murder is committed in attacking a country it is not considered wrong; it is applauded and called righteous." "Thank you for your service" has become a common phrase societies use to acknowledge the atrocities of the military in the name of defense, freedom, and peace. According to Mo Ti such an action made no sense, he maintains "if a man calls black black if it is seen on a small scale, but calls black white when it is seen on a large scale, then he is the one who cannot tell black from white"(Goldstein2004,71).

\subsection{Tracing the Genesis of the Military as an Institution}

The organizing principle of the military for any society is for war in the name of defence and territorial protection. The study of military doctrine has become an academic discipline where the study is restricted in its written form. The question is "whether there existed written doctrines before the Renaissance is a matter of interpretation" (Hoiback, 2013, 25). Some archaeological evidence suggest that elements of warfare began appearing as early as 10,000 years ago, as frontier tensions began to develop between rapidly evolving agricultural societies ${ }^{4}$ (Cioffi-Revilla, 1996). Not long after the establishment of the earliest known cities in Lake Uruk Mesopotamia in 3500 BC, written evidence of battle, "metal weapons and helmets began appearing as Mesopotamia and Elam started to engage in conflicts" (3100 BC) ${ }^{5}$ (Oates 1993,403). However, according to Cioffi-Revilla, the first reliably recorded wars occurred circa 2700 B.C. In fact, one of the oldest military documents ever found called the Royal Standard dated to roughly the same time period contains details of the Sumerian army. ${ }^{6}$ The first evidence of an organized army may be traced back to 2450 B.C., as the Stele of Vultures depicts King Eannatum of Lagash leading an obvious contingent of troops. ${ }^{7}$ Later the first evidence of a specialized fighting force came in the middle of eighteen century $\mathrm{BC}$, as the development and use of the chariot demanded a level of specialization not required previously in the course of battle. ${ }^{8}$ Yet perhaps the Biblical Joshua, who is often credited with in the advent of psychological warfare and intelligence gathering during his siege of Jericho, made the greatest contribution to modern warfare. ${ }^{9}$ The Iron Age saw yet another advancement of warfare, as the invention of iron allowed for a larger, more diversified fighting force, allowing armies to grow from just a few thousand members to Egypt's fighting force numbering 100,000 men. ${ }^{10}$

The Middle East region is often referred to as the "Cradle of Civilization (Khan Academy 2019). Not only is this region the location of the first recorded evidence of militarism, but also it is the birthplace of many of the concepts of armed conflict. Initially, conflicts spawned from disputes over resources; however, as the birthplace of three of the world's most influential religions; Islam, Christianity, and Judaism, natural conflicts among believers were inevitable. Therefore, in addition to be credited as the "Cradle of Warfare" the region may also lay claim to being the cradle of genocide, political/religious misunderstanding, terrorism, and jihad. ${ }^{11}$ The organization of armies was to fight and protect a given group's (this could be society, tribe, state, or nation) territory. The core function of the military-kill and destroy- since its inception has not changed but rather other activities in terms of protection have been added. From the Iron Age till now, the military as an institution has become a very lethal fighting force as a result of advancement in technology, which includes the use of aircrafts,

\footnotetext{
${ }^{3}$ See also Tzu, Sun Tzu. The art of war. Translated by Samuel B. Griffith. NY. Oxford, 1963, p. 22.

${ }^{4}$ Meistrich, I. (2005). Military history: The birthplace of war. In Historynet. Retrieved January 25, 2018, from http://www.historynet.com/military-history-the-birthplace-of-war.html (Originally published in $M H Q:$ The Quarterly Journal of Military History: Spring 2005)

${ }^{5}$ Ibid

${ }^{6}$ Ibid

${ }^{7}$ Ibid

${ }^{8}$ Ibid

${ }^{9}$ Ibid

${ }^{10}$ Ibid

${ }^{11}$ Ibid
} 
submarines, missiles, nuclear weapons, and precision bombs. So, what is the exact role of the military? To defend, protect, or destroy? Could these be acts of terrorism?

\subsection{The Role of the Military}

Little has changed regarding the functions of the military since the advent of civilization. Its purpose is still to defend and protect the interest of the people, society, state, and nation that it serves. However, the role of military in society has become somewhat more complex and refined. In many nations, democratic governments, the military is now subject to civilian control as the commander-inchief is the elected political leader of the country, who is more likely to be a civilian who may have no military background or understand its doctrine. This is not to imply that active military leaders do not have a role in decisions regarding the use of force, "their professional competence provides them enormous amount of influence on such decisions" (Bland 1999,11).Nevertheless, in a democratic country, such as the USA, the UK, Ghana, France, and Nigeria, the military does not lead a nation-it serves. ${ }^{12}$ However, under authoritarian or military governments, the face of the government is the military, for example, Cuba since its revolution under Fidel Castro, Ghana from 1966-1992 under various military leaders including Flt. Lt. Jerry John Rawlings, General Ignatius Kutu Acheampong, and many other countries including Brazil and Venezuela that experienced military dictatorship one time or the other. But more and more countries adopting democratic principles and governance are adopting the civilian-commander-in-chief approach where the military despite its power takes instructions from the civilian commander-in chief who consults with the military generals. The US State Department defines civil-military relations through six key principals:

- Civilians need to direct their nation's military and decide issues of national defense, not because they are necessarily wiser than the military professions, but precisely because they are the people's representatives and as such are charged with the responsibility for making these decisions and remaining accountable for them.

- The military in a democracy exists to protect the nation and the freedom of its people. It does not represent or support any political viewpoint or ethnic and social group. Its loyalty is to the lager ideals of the nation, to the rule of law, and to the principle of democracy itself.

- Civilian control assures that a country's values, institutions, and policies are the free choices of the people rather than the military. The purpose of the military is to defend society not define it.

- Any democratic government values the expertise and advice of military professionals in reaching policy decisions about defense and national security. Civilian officials rely upon the military for expert advice on these matters and to carry out the decision of the government. But only the elected civilian leadership should make the ultimate decisions-which the military then implements in its sphere.

- Military figures may, of course, participate fully and equally in the political life of their country just like any other citizen- but only as individual voters. Military people must first retire from military service before becoming involved in politics; armed services must remain separate from politics. The military are the neutral servants of the state, and the guardians of society.

- Ultimately, civil control of the military ensures that defense and national security issues do not compromise the basic democratic values or majority rule, minority rights, and freedom of speech, religion, and due process. It is the responsibility of all political leaders to enforce civilian control and the responsibility of the military to obey the lawful orders of civilian authority. ${ }^{13}$

This has not always been the basis for civil-military relations. For quite some time it was the prevalent conviction that "politics should not interfere with the army- rather than the army should not interfere with politics" (Bland 1999, 12). The evolution of thought in connection to civil military relations is responsible for a variety of different views on the military's role in society. Even now, people around the world hold diverse views of the role of the military in their countries, in addition to differing ideas

\footnotetext{
${ }^{12}$ Principles of democracy: Civil-Military relations (2005). In InfoUSA. Retrieved February 2018, from http://infousa.state.gov/government/overview/civil.html (InfoUsa is maintained by the Bureau of International Information Programs of the U.S. State Department).

${ }^{13}$ Ibid
} 
of what the military should look like. Despite the diverging view of this institution, the budget of the military keeps soring while other sectors like education, infrastructure, and health may be on the decline especially in developing countries. For example, Table 1 shows how much regions spend on the military from 2005-2012.

According to a study by the Stockholm International Peace Research Institute (SIPRI), countries are more likely to increase their military spending in the name of security and defence. What is interesting is that all regions did increase their military spending and such a trend is more likely to be sustained in the foreseeable future under the disguise of fighting terrorism. Table 2 shows the amount of money various countries are investing in the military. It should be noted that on the average from 2003 to 2012 most countries did increase their military spending regardless of the financial status of each country.

Table1: Military Expenditure by Regions: 2005-2012*

$\begin{array}{lllllllll}\text { YEAR } & 2005 & 2006 & 2007 & 2008 & 2009 & 2010 & 2011 & 2012 \\ \text { World Total } & \mathbf{1 4 2 3} & \mathbf{1 5 2 8} & \mathbf{1 6 0 9} & \mathbf{1 7 1 5} & \mathbf{1 7 4 4} & \mathbf{1 7 4 9} & \mathbf{1 7 4 2} & \mathbf{1 7 5 6} \\ \text { Africa } & 24.2 & 25.9 & 26.7 & 30.4 & 31.8 & 33.8 & 37.8 & 39.2 \\ \text { North Africa } & 7.9 & 7.9 & 8.5 & 10.1 & 11.1 & 12 & 15.1 & 16.4 \\ \text { Sub-Saharan Africa } & 16.3 & 18 & 18.1 & 20.4 & 20.7 & 21.8 & 22.8 & 22.7 \\ \text { Americas } & 651 & 665 & 685 & 737 & 793 & 817 & 808 & 782 \\ \text { Central America and the Caribbean } & 5.1 & 5.6 & 6.2 & 6.3 & 7.1 & 7.7 & 8 & 8.5 \\ \text { North America } & 598 & 607 & 625 & 671 & 724 & 743 & 735 & 708 \\ \text { South America } & 48.7 & 52 & 54.6 & 59.5 & 62.2 & 66.3 & 65.2 & 65.9 \\ \text { Asia and Oceania } & 260 & 275 & 296 & 313 & 349 & 356 & 369 & 390 \\ \text { Central and South Asia } & 46 & 46.6 & 47.9 & 52.8 & 60.6 & 61.7 & 62.9 & 59.8 \\ \text { East Asia } & 167 & 180 & 194 & 204 & 229 & 235 & 247 & 268 \\ \text { Oceania } & 24.3 & 24.9 & 28.3 & 28.9 & 30.3 & 30 & 31.3 & 33.7 \\ \text { South East Asia } & 24.3 & 24.9 & 28.3 & 28.9 & 30.3 & 30 & 31.3 & 33.7 \\ \text { Europe } & 387 & 397 & 408 & 419 & 428 & 419 & 411 & 407 \\ \text { Eastern Europe } & 55.5 & 63 & 70 & 76.6 & 78.9 & 80.2 & 87 & 100 \\ \text { Western and Central Europe } & 331 & 334 & 338 & 343 & 349 & 338 & 324 & 307 \\ \text { Middle East } & 100 & 107 & 113 & 110 & 112 & 118 & 123 & 134\end{array}$

*Source: SIPRI, Yearbook 2013: Armaments, disarmament and international security. Oxford University Press. Pp. 128-129. All figures are in US\$ b. at constant (2011) exchange rates.

Table2: Military Spending for some selected Countries from 2003-2012*

$\begin{array}{lllllllllll} & \mathbf{2 0 0 3} & \mathbf{2 0 0 4} & \mathbf{2 0 0 5} & \mathbf{2 0 0 6} & \mathbf{2 0 0 7} & \mathbf{2 0 0 8} & \mathbf{2 0 0 9} & \mathbf{2 0 1 0} & \mathbf{2 0 1 1} & \mathbf{2 0 1 2} \\ \text { Ghana* } & 81 & \mathbf{7 9} & \mathbf{7 9} & 85 & 130 & 114 & 127 & 129 & 99 & 119 \\ \text { Iraq } & \text { N/A } & 1882 & 2541 & 1824 & 2724 & 3401 & 3225 & 3782 & 5905 & 5693 \\ \text { Israel* } & 17279 & 16514 & 15898 & 16940 & 16447 & 15796 & 15933 & 15398 & 15163 & 15536 \\ \text { Mexico* } & 3941 & 3797 & 4081 & 4440 & 5013 & 5019 & 5689 & 6203 & 6472 & 7103 \\ \text { Nigeria } & 1190 & 1159 & 1034 & 1067 & 1239 & 1741 & 1825 & 2143 & 2386 & 2100 \\ \text { Russia* } & 42658 & 44379 & 50505 & 56417 & 61824 & 67986 & 71566 & 72918 & 78330 & 90646 \\ \text { Saudi Arabia } & 25751 & 28628 & 34495 & 39294 & 45264 & 44425 & 45655 & 48511 & 48531 & 54218 \\ \text { Syria } & 2322 & 2326 & 2339 & 2104 & 2236 & 2027 & 2301 & 2366 & 2495 & \text { N/A } \\ \text { United } & 50778 & 55344 & 57983 & 58883 & 60429 & 64901 & 70108 & 72038 & 71140 & 67162 \\ \text { States* } & 1 & 1 & 1 & 7 & 2 & 0 & 7 & 6 & 2 & 8\end{array}$

*Source: SIPRI, Yearbook 2013: Armaments, disarmament and international security. Oxford University Press. Pp. 174-180. (Figures are in billions of the local currencies of the various countries.

Prior to 9/11 it was the general consensus that the realities of a post-Cold War world would necessarily dictate that traditional military powers, like the UK, revamp its military operations by focusing on smaller, busier, more flexible force, whose budget reflects a smaller percentage of the state's gross national product (Dandeker 1994, 645). However, those goals were predicted on the supposition that the end of the Cold War signalled a decrease in international hostilities. This has not to be the case; the attacks on 9/11 and rising tensions in the Middle East altered the perceptions of many concerning the de-emphasis of military power. Yet, as more nations make the move toward democracy and individual liberty, especially in third world countries, it may very well be possible that a decline in international hostilities could eventually spell a softening of hard-core military posturing and that civil-military relations across the globe might grow. In fact, with global political uncertainty 
and tensions, most countries are rather investing (financially- purchasing new military equipment), especially powerful nations, in building up their military. Countries have used their military institutions to extend their political agenda or quest for regional or global power. For example, in 2017 the USA and North Korea (President Donald Trump and President Kim Jong-un respectively) did engage in orotundity regarding whose nuclear weapon is the most lethal. Unfortunately, some individuals have charismatically utilized the military institution to gain political power. For example, J.J. Rawlings of Ghana in 1981, Idi Amin of Uganda in 1971, Napoleon Bonaparte of France in 1799, Francisco Franco of Spain in 1936, Muammar Al Gaddafi in 1969, and Augusto Pinochet of Chile in 1973. Such individualist ambitions occur mostly in developing countries where citizens of those nations are terrorized by their leaders through the use of the military institution. But terrorism, as understood depending on who is defining it, has placed the military into a very controversial position on global and national self-defense.

\section{THE MiLITARY AND TERRORISM}

Does the military as an institution engage in terrorism? Again, it goes back to who is defining it. To most Palestinians, if not all, they are constantly terrorised by the Israeli Army, while a counter argument would be that the Israelis are trying to confront Palestinian terrorists who are constantly sending rockets into Israeli settlements; hence, the army is defending and protecting Israelis from Palestinian terrorists (Ageel 2016). The next question is would the invasion by a powerful nation be considered terrorism since the natives have to live under the atrocities of an occupied foreign army? For example, how does one categorize these invasions and occupations of France, Britain, Germany, Portugal in colonized African and South American countries? The USA army in Iraq, Afghanistan, and Puerto Rico, the UK in Afghanistan or the USSR in Afghanistan or Russia in Ukraine?

Whether or not states through their military engage in terrorism depends on which lens one uses (De Nevers 2007).; undeniably, everyone views terrorism within their own political context. For example, one is more likely to interpret current events in terrorism as if those events have no historical precedent. The military and terrorism as already established "is by no means a modern phenomenon. Nor does terrorism arise from a political vacuum" (Martin2006, 5). There are political, religious, cultural, and economic climate, in many parts of the world, "which foster the conditions for terrorism to thrive" (Piazza 2007, 521). As Hunter $(1991,353)$ noted, "those who complain about terrorist acts want to maintain the existing power equation that favors them and to limit the spread of ideas that could undermine the existing balance of power."Hunter's observation affirms the intent of the colonial and slave masters who still want to rule the world through their military might and maintain weapon possession but oppose any other country from acquiring similar weapons, such as nuclear.

According to Piazza, many so-called failed states are willing to tolerate large-scale terroristic operations within their borders in exchange for material compensation, political support, or terrorist services during times of political uproar. States that embrace terrorism as a tool of foreign policy, using those services and surrogates as means of waging war covertly, can be described as statesponsors of terror (Hoffman 2006). The reality is that every country, especially the powerful nations use their military might not only to threaten weaker ones to abide by their policy agenda, but also punish those weaker nations when they fail to comply to the demands of the powerful nations. For example, when Saddam Hussein of Iraq was falsely accused of harbouring weapons of mass destruction by the US under the George W. Bush administration, Iraq was invaded in 2003 by the socalled Coalition of the Willing where the Iraqi president was eventually removed from office and killed. Similar examples can be cited in Libya, Democratic Republic of Congo, Ghana, Afghanistan, Egypt, and Syria where powerful nations, especially the West and Russia, exercise their unwelcome military might.

The 1979 Iranian hostage crisis, in which 52 Americans from the USA Embassy were held prisoners in Tehran, is the single most pivotal event in the emergence of state-sponsored terrorism as a weapon of state and instrument of foreign policy. Since the surrogates who claimed public responsibility for the attacks were Iranian militant students, the government had no official involvement in the episode, precluding the acts from being labelled as state terror (Hoffman 2006,186-187). As Hoffman noted, the use of surrogates by states offers a certain amount of flexibility and a variety of advantages. Many terrorist groups are desirous of the media attention they attract with such heinous acts. He argues states that sponsor terror are, typically, more concerned with bringing to bear pressure on their 
enemies, and are less burdened by the need to attract attention to their cause. Another advantage for the state that sponsors terrorists, as opposed to ordinary terrorists who act alone, is that those states "have the benefit of not being concerned with the reactions of the local population" (Hoffman 2016, 193). The problem is no state agrees it sponsors terrorists. There is no evidence in the terrorism literature where the USA, Britain, Iran, Russia, Germany, France, Portugal, China, South Africa, Israel, Ghana, Israel or Palestine has officially claimed to be supporting or sponsoring terrorists. Rather it is nations that label groups and other states as sponsors of terrorism - something all nations are guilty of. For example, all these groups, the CIA (USA), KGB (USSR), MI6 (Britain), and other security (intelligence)services of all nations by way of intelligence collection to protect their various countries clandestinely through their nocturnal activities commit the same crimes as terrorists (Perkins 2006; Valentine 2017).

If these national security agencies are officially or unofficially involved in clandestine terrorist activities, why then do some selected nations claim to be fighting terrorismwhen they are guilty of terrorism? As noted earlier by their very definitions, states cannot be accused of terrorism when they are fighting a war. Ganor (2002) defines the issue this way:

The term terrorism is superfluous when describing the actions of sovereign statenot because states are on a higher moral level, but because according to international conventions, any deliberate attack upon civilians in wartime by regular military forces is already defined as a war crime (289).

According to Gage (2011) the term "terrorism" should be reserved for those acts, which are committed by non-state actors. So, Gage wants us to believe that states and the military do not terrorise their enemies. Terrorism takes the lives of other human beings whether it is an individual, gangs, groups, societies, the military or nations, the acts of terrorism need condemnation. Unfortunately, countries reward the military when it drops bombs on civilians in other nations, those considered enemies. The atrocities committed against civilians in WW II were the primary impetus for the negotiation of the Geneva Conventions and the creation of International Humanitarian Law (Bianchi 2011). But when nations go to war the military does not only kill their fellow human beings (so-called enemies or bad guys) in uniform. Instead, they kill civilians and destroy their properties. The so-called principle of distinction provided for in Convention IV relative to the Protection of Civilian Persons in Time of War, declare that civilians cannot be attacked and are protected in any number of ways, including from "collective punishment, reprisals, and acts of terrorism" (Ivan 2011,110). According to Greenwood $(2002,313)$,every state is entitled to the use of force in certain circumstances, but hostilities must be conducted in such a way that complies with international humanitarian law, this is often referred to as the "law of armed conflict" or the "law of war." Both the UK's Joint Service Manuel of the Law of Armed Conflict (2004) and the US's Law of War Desk Book (2011) acknowledge that any exemption to the prohibition of use of force must be justified by the existence of a viable legal basis in international law (Bovarnick et al. 2011).

In the United States' Law of War Deskbook, the legal basis for the use of force is outlined clearly and deliberately. The use of force in certain situations must abide by a specific set of criteria. Primary among them is the use of force be "necessary proportional and that the use of force be viewed as a last resort" (Bovarnik et al. 2001, 37). Additionally, both the UK and US laws clearly prohibit intentional attacks against non-combatants (Bovarnik et al. 2001; Great Britain Ministry of Defense 2004). Moreover, while the US law of war does not mention terrorism specifically within the chapter entitled "War Crimes and Command Responsibilities", it does explicitly state that every violation of the law of war is a crime, including breaches of the aforementioned Common Article 3 of the NIAC, which expressly "prohibits crimes against humanity, which include widespread or systematic attacks on civilian populations" (Bovarnik et al. 2001, 187). The UK, on the other hand, does expressly prohibit terrorism, according to the Great Britain Ministry of Defense:

Acts or threats of violence, the primary purpose of which is to spread terror among the civilian population are prohibited. This rule reinforced the rule that civilians are not to be made the object of direct attack. $(2004,67)$

It is the position of these states that it is a war crime for members of their military to engage in acts of terrorism. This, coupled with the other statutes of international law seem to lead credence to the notion that it is indeed possible for the military, and by extension a state, to engage in terrorism. This 
runs counter to the position of Ganor (2002) and many other scholars who deem it impossible to define such acts (military atrocities) by states as terrorism because any deliberate attack upon civilians in wartime by regular military forces is already defined as a war crime. In fact, war is a crime since nations and their military institutions go to war to kill and destroy.

\section{CONCLUSION}

The greatest enemy of the human race is the human race itself, as it continues to divide humanity into compartments of race, religion, geographical location, and other superficial categorization. Terrorism has always been a complicated issue and almost impossible to define given its relativity. Since the first cases of documented terrorism committed by the Sicarii in 70AD to the attacks on the US on9/11 and thereafter, the definition of terrorism has fluctuated with the times, while the violence (killing people and destruction) remain constant. It is our individualistic or societal perceptions of terror that have proven the most difficult challenge to producing a universally accepted definition of terrorism. Bahan (2009) argues, "in order for international terrorism to be universally defined, the international community must be sensitive to the diverging specific normative values of different states" and actors. However, if we may, as Ganor (2002) suggests, create an objective definition that is based on accepted international law and principles concerning behaviours that are permitted among nations in conventional wars; and then further distinguish the non-state actors that deliberately use violence or the threat of violence to attain political, religious, and ideological objectives, then we may differentiate between "the means used to achieve these goals." This clearly delineates terrorism as a tactic separate from the values or justifications of any state or individuals within states, choosing to use such tactics.

The military as an institution originated to defend and protect the societies it serves. Unfortunately, with technological advancement in weaponry, the military has become a lethal institution of destruction. Now the question is: should the atrocities of the military be considered acts of terrorism? The historical function of the military has not changed but the ability to kill and destroy has improved astronomically as a result of technology and other weapons, such as chemical, nuclear, and biological. Regardless of how terrorism is defined, we are destroying ourselves as no amount of military power can eliminate terrorism, if it would ever be defined globally. Different constituencies have divergently interpretation of the role of the military. As long as nations use this institution to either silence or threaten those they politically, culturally, or ideologically disagree with, the selective justification and reward for military atrocities will forever fuel terrorism.

\section{REFERENCES}

[1] Ageel, Ghada 2016. Apartheid in Palestine: Hard laws and harder experiences. Edmonton, CDN: University of Alberta Press.

[2] Anderson, D. 2005. Histories of the hanged: The dirty war in Kenya and the end of empire. New York, NY: W.W. Norton \& Company.

[3] Bahan, C.A. 2009. "International terrorism: The legitimization of safe harbor states in international law."NYL Sch. L. Rev.54, 333.

[4] Bianchi, A. 2011. "Terrorism and armed conflict: Insights from a law \& literature perspective."Leiden Journal of International Law24 (1), 1-21.

[5] Bland, D.L. 1999. “A unified theory of civil-military relations.”Armed Forces \& Society26 (10), 7-25.

[6] Bovarnick J.A., Marsh J.J., Musselman G.S., Reese J.B., Reeves S.R., BarnsbyR.E.,Pedden, I. 2011. Law of War Deskbook. Charlottesville, VA: International and Operational Law Dept., The U.S. Army Judge Advocate General's Legal Center and School.

[7] Bruce, G. 2013. "Definition of terrorism: Social and political effects." Journal of Military and Veterans Health. 21(2) 26-30.

[8] Carr, C. 2007. "Terrorism: Why the definition must be broad.”World Policy Journal 47-50.

[9] Cioffi-Revilla, C. 1996. "Origins and evolution of war and politics.”International Studies Quarterly, 1-22.

[10] Cronin, A. 2005. "Behind the curve: Globalization and international terrorism." In Readings in World Politics: A New Era. Edited by Steven L Spiegel, Jennifer Morrions, Fred L. Wehling, and Kristen P. Williams. (340-359). United States: Thomson and Wadsworth.

[11] Dandeker, C. 1994. "New times for the military: Some sociological remarks on the changing role and structure of the Armed Forces of the advanced societies."British Journal of Sociology, 637-654. 
[12] De Nevers, R. 2007. "Sovereignty and ethical argument in the struggle against state sponsors of terrorism."Journal of Military Ethics, 6(1), 1-18.

[13] Elkins, C. 2005. Imperial reckoning: The untold story of Britain's gulag in Kenya. New York: Henry Holt and Company.

[14] Fausto, B. 1999. A concise history of Brazil. New York, NY: Cambridge University Press.

[15] Fine, J. 2010. "Political and philological origins of the term "terrorism" from the ancient near east to our times."Middle Eastern Studies, 46(2), 271-288.

[16] Gage, B. 2011. "Terrorism and the American experience: A state of the field."Journal of American History, 98(1), 73-94.

[17] Ganor, B. 2002. “Defining terrorism: Is one man's terrorist another man's freedom fighter?"Police Practice and Research.3 (4), 287-304.

[18] Goldstein, J. 2004. International relations $\left(5^{\text {th }}\right.$ ed). New York, NY Longman.

[19] Great Britain, Ministry of Defense (GBMOD). (2004). The Manual of the Law of Armed Conflict. Oxford: Oxford University Press.

[20] Greenwood, C. 2002. "International law and the war against terrorism.”International Affairs, 78(2), 301317.

[21] Gupta, D.K. 2011. “Terrorism, history, and historians: A view from a social scientist.”Journal of American History, 98(1), 95-100.

[22] Hoffman, B. 2006. Inside terrorism. USA: Colombia University Press.

[23] Hoiback, Harald 2013. Understanding Military Doctrine: A Multidisciplinary Approach. New York, NY, Routledge.

[24] Hunter, Shireen T. 1991. "Terrorism: A balance sheet." In At Issues Politics in the World Arena (6" ed). Edited by Steven L Spiegel (350-365). New York: St. Martin's Press.

[25] Ivan, G. 2011. "War crimes according to the new penal code."Bulletin Scientific,16(2), 107-113. International Legal Instruments to Counter Terrorism (n.d.). United Nations. Retrieved January 25, 2018, from http://www.un.org/terrorism/instruments.shtml

[26] Kaplan, J. 2011. History and terrorism. Journal of American History,98(1), 101-105.

[27] Khan Academy. 2019. The cradle of civilization. Retrieved from https://www.khanacademy.org/ humanities/ancient-art-civilizations/ancient-near-east1/the-ancient-near-east-an-introduction/a/the-cradleof-civilization

[28] Matthews, E. Gerald. 2002. E pluribus unum: Justice, liberty, and terror: An analysis of Western terrorism on people of African descent in the diaspora. Mason, $\mathrm{OH}$ : Thomson Custom Publishing.

[29] Perlo-Freeman, Sam, C Solmirano C, \& Helen Wilandh H. 2013. "Global developments in military expenditure." In SIPRI yearbook 2013: Armaments, disarmaments and international security. Oxford University Press.

[30] Legislative Requirements and Key Terms 2006. U.S. Department of State. Retrieved February 10, 2019, from http://www.state.gov/documents/organization/65464.pdf.

[31] Martin, Gus 2006. Understanding terrorism: Challenges, perspectives, and issues. USA, Page Publications, Inc.

[32] Oates, J. 1993. "Trade and power in the fifth and fourth millennia BC: New evidence from northern Mesopotamia."World Archaeology, 24(3), 403-422.

[33] Perkins,J. 2004. Confessions of an economic hit man. New York, NY. Penguin Group.

[34] Piazza, J.A. 2007. "Draining the swamp: Democracy promotion, state failure, and terrorism in 19 Middle Eastern countries."Studies in Conflict \& Terrorism, 30(6) 521-539.

[35] Saul, B. 2005. "Definition of 'terrorism' in the UN Security Council: 1985-2004."Chinese Journal of International Law,4(1) 141-166.

[36] Schmid A. P.,\&Johgman A. J. 2006. Political terrorism. London: Transactional Publishers.

[37] Stockholm International Peace Research Institute. 2013. SIPRI, Yearbook 2013: Armaments, disarmament and international security. Oxford University Press.

[38] Smith, M. 1971. "Zealots and Sicarii: Their origins and relation."The Harvard Theological Review,64(1) $1-19$.

[39] Symonides, J.Z. 2001. "International law and the struggle against terrorism."The Polish Quarterly of International Affairs (Warsaw), 10(4), 22-39.

[40] Valentine, D. 2017. The CIA as organized crime. How illegal operations corrupt America and the world. Atlanta, GA. Clarity Press. 
[41] Young, Reuven 2006. "Defining terrorism: The evolution of terrorism as a legal concept in international law and its influence on definitions in domestic legislation." BC International and Comparative Law Review, 23(1) 23-105.

[42] Zeitlin, S. 1965. “Masada and the Sicarii.”The Jewish Quarterly Review, 299-317.

Citation: Kwame Badu Antwi-Boasiako, John HamiHasbun. "Terrorism and the Military Institution: History and Definitions" International Journal of Political Science (IJPS), vol 5, no.4, 2019, pp. 35-47. doi: http://dx.doi.org/ 10.20431/2454-9452.0504006.

Copyright: (C) 2019 Authors. This is an open-access article distributed under the terms of the Creative Commons Attribution License, which permits unrestricted use, distribution, and reproduction in any medium, provided the original author and source are credited. 